\title{
PENINGKATAN AKTIVITAS DAN HASIL BELAJAR SISWA METODE PEMBELAJARAN CONTEXTUAL TEACHING LEARNING (CTL) PADA SISWA KELAS VIII-H SMP NEGERI 1 STABAT
}

\author{
Riahta \\ Surel : riahta.s.pd@gmail.com
}

\begin{abstract}
ABSTRAK
Tujuan penelitian ini yaitu untuk Meningkatkan Aktivitas dan Hasil Belajar Siswa. Intrumen pengumpul data berupa tes tertulis dan Lembar Observasi psikomotorik siswa digunakan untuk mengumpulkan data mengenai keterampilan Presentase. Dari hasil belajar tersebut terjadi peningkatan dari siklus I ke siklus II, hasil belajar diatas dapat disimpulkan telah mencapai ketuntasan belajar secara klasikal yang ditargetkan yaitu $85 \%$ tuntas belajar dalam 1 kelas dan hasil pengamatan aktivitas belajar siswadiperoleh data sebagai berikut, untuk siklus I memperoleh nilai diantaranya: Kelompok Pasar lokal 62,5, Kelompok Pasar harian 68,75, kelompok Pasar mingguan 50, Kelompok pasar bulanan 68,75 dan kelompok pasar tahunan 56,25 terjadi peningkatan yang signifikan pada siklus II yaitu: Kelompok Pasar lokal 87,5, Kelompok Pasar harian 93,75, kelompok Pasar mingguan 87,5, Kelompok pasar bulanan 93,75 dan kelompok pasar tahunan 81,25.
\end{abstract}

Kata Kunci: Contextual Teaching and Learning, Aktivitas, Hasil belajar

\section{PENDAHULUAN}

Sehingga seorang guru harus dapat melaksanakan fungsinya sebagai agen pembelajar yang berperan sebagai fasilitator, pemacu, perekayasa pembelajaran,dan pemberi inspirasi belajar bagi peserta didik.

Mengarahkan peserta didik untuk

melakukan sendiri aktivitas pembelajaran membutuhkan bantuan dari guru yangberperan sebagai fasilitator. Bantuan ini diperlukan untuk semua prosespembelajaran, begitu pula pembelajaran Ilmu Pengetahuan Sosial (IPS).

Sehubungan dengan pemilihan dan penggunaan metode yang ada untuk pembelajaran IPS, maka itu guru perlu lebih dahulu mengetahui apa yang menjadi tujuan pembelajaran IPS. Edwin Fenton menyebutkan tiga tujuan pendidikan IPS sebagai berikut: 1) Pemerolehan pengetahuan, 2) Pengembangan keterampilan inkuiri, 3) Pengembangan sikap-sikap dan nilainilai.Ketiga tujuan ini didasarkan pada ranah taksonomi Benjamin S. Bloom. Tujuan penididikan menurut Benjamin S. Bloom dan kawankawan meliputi tujuan pendidikan kognitif (cognitif domain), tujuan pendidikan afektif (afectif domain)dan psikomotorik tujuan pendidikan domain). (psycomotoric Berkaitan dengan tujuantujuan pendidikan IPS di atas, maka guru harus memilih metode yang dapat digunakan agar tujuan-tujuan 
Riahta : Peningkatan Aktivitas dan Hasil Bel ....

pendidikan itu dapat tercapai. Refleksi diri yang guru lakukan selama mengajar di SMP Negeri 1 Stabat Kab. Langkat khususnya di kelas VIII-H di semester ganjil yaitu 1) selama ini mengajar dengan menggunakan ceramah, sehingga siswa banyak tidak fokus mendengarkan dan sibuk dengan kegiatannya sendiri, 2) ketika guru mengajukan pertanyaan siswa menjawab dengan asal (jawaban tidak benar), 3) dan jika diminta tanggapan terhadap materi yang sedang diajarkan siswa diam.

Dari hasil refleksi diri tersebut proses pembelajaran di atas ternyata belum memberikan dampak yang baik terhadap peningkatan aktivitas dan hasil belajar siswa. Hal ini disebabkan karena proses pembelajaran yang dilakukan masih menggunakan metode yang kurang menarik perhatian siswa. Sehubungan dengan permasalahan tersebut, maka perlu diadakan tindakan perbaikan-perbaikan sebagai upaya meningkatkan aktivitas dan hasil belajar siswa dalam pembelajaran IPS.

Hasil diskusi dengan teman sejawat, maka dirasa perlu adanya suatu perubahan baru dalam pelaksanaan pembelajaran IPS di SMP Negeri I Stabat Kab. Langkat agar siswa lebih aktif dan kreatif sehingga bisa berkembang sesuai dengan tingkat kemampuan masingmasing. Dalam usaha untuk meningkatkan keaktifan dan hasil belajar siswa dalam proses pembelajaran bisa dengan menggunakan salah satu model dari pembelajaran cooperative learning. Model pembelajaran yang diterapkan adalah model pembelajaran Contextual Teaching Learning (CTL), yaitu sistem pembelajaran yang cocok dengan kinerja otak, untuk menyusun pola-pola yang mewujudkan makna, dengan cara menghubungkan muatan akademis dengan konteks kehidupan seharihari peserta didik.

CTL adalah sebuah proses pendidikan yang bertujuan untuk menolong para siswa melihat siswa melihat makna didalam materi akademik yang mereka pelajari dengan cara menghubungkan subyek-subyek akademik dengan konteks dalam kehidupan keseharian mereka. Adapun tujuan Model pembelajaran CTL ini bertujuan: 1) untuk memotivasi siswa untuk memahami makna materi pelajaran yang dipelajarinya dengan mengkaitkan materi tersebut dengan konteks kehidupan mereka seharihari sehingga siswa memiliki pengetahuan atu ketrampilan yang secara refleksi dapat diterapkan dari permasalahan kepermasalahan lainya; 2) agar dalam belajar itu tidak hanya sekedar menghafal tetapi perlu dengan adanya pemahaman; 3) Model pembelajaran ini menekankan pada pengembangan minat pengalaman siswa.

Penggunaan

model pembelajaran CTL dimaksudkan untuk mempermudah siswa dalam mengikuti pembelajaran sehingga siswa termotivasi untuk terlibat 
secara aktif dan tidak merasa cepat bosan dalam mengikuti proses pembelajaran. Berdasarkan uraian tersebut di atas maka peneliti ingin melakukan penelitian tindakan kelas untuk memperbaiki pembelajaran selama ini dengan judul "Peningkatan Aktivitas dan Hasil belajar Siswa Mata Pelajaran IPS Melalui Metode Pembelajaran Contextual Teaching Learning (CTL) pada Siswa Kelas VIII-H SMP Negeri 1 Stabat Tahun Ajaran 2016/2017”.

Berdasarkan permasalahan yang telah diuraikan pada latar belakang masalah diatas dapat dirumuskan masalah sebagai berikut:

1. Bagaimana cara menerapan metode Contextual Teaching Learning (CTL) Untuk Meningkatkan Aktivitas Belajar dan Hasil Belajar Siswa Kelas VIII-H SMP Negeri 1 Stabat Kab. Langkat TP. 2016/2017".

2. Bagaimanakah peningkatan Aktivitas Belajar dan Hasil Belajar setelah menerapkanmetode Contextual Teaching Learning (CTL) di Kelas VIII-H SMP Negeri 1 Stabat Kab. Langkat TP. 2016/2017".

\section{METODE PENELITIAN}

Subjek pada penelitian ini berjumlah 37 siswa SMP Negeri 1 Langkat kelas VIII-H.

Selama perbaikan pembelajaran dilaksanakan, penulis selaku peneliti yang membutuhkan teman sejawat untuk melakukan observer mengamati aktivitas siswa selama proses pembelajaran berlangsung dan mencatat hal-hal yang penting untuk perbaikan pembelajaran. Prosedur perbaikan pembelajaran meliputi kegiatan pelaksanaan penelitian tindakan kelas yang disusun oleh Kemmis dan Mc Targgat yang terdiri dari 4 tahap yaitu perencanaan tindakan observasi dan refleksi, serta pelaksanaan penelitian ini direncanakan 2 siklus.

\section{HASIL PENELITIAN DAN PEMBAHASAN}

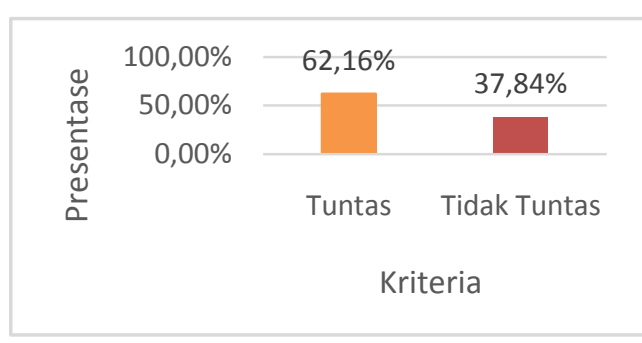

\section{Gambar.Ketuntasan Hasil Belajar Siswa Pada Siklus I}

Dari grafik diatas dapat dilihat hasil belajar siswa pada siklus I pada mata pelajaran IPS di SMP Negeri I Stabat Kelas VIII- H dengan menggunakan metode Pembelajaran Contektual Teaching and Learning (CTL), diperoleh 23 orang tuntas belajar atau sekitar $62,16 \%$ dan 14 orang atau sekitar $37,48 \%$ tidak tuntas belajar. Dari hasil belajar tersebut terjadi peningkatan dari proses pembelajaran sebelum menerapkan CTL namun, hasil belajar diatas belum mencapai ketuntasan belajar secara klasikal 
Riahta : Peningkatan Aktivitas dan Hasil Bel ....

yang ditargetkan yaitu $85 \%$ tuntas belajar dalam 1 kelas.

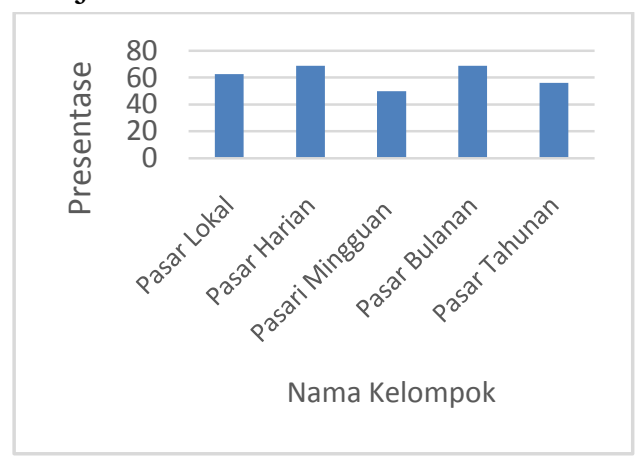

Grafik Observasi Aktivitas Siswa

Dalam Presentasi Pada Siklus I

Dari gambar diatas dapat dilihat bahwa aktivitas yang diamati selama pembelajaran dengan menerapkan metode Pembelajaran Contektual Teaching and Learning (CTL) ada 4 aspek yang diamati yaitu: kemampuan presentasi, kemampuan berargumentasi, kemampuan menjawab dan penguasaan materi.

Dari 4 aspek yang diamati dapat dilihat bahwa 3 kelompok dalam aspek kemampuan berargumentasi dan kemampuan menjawab pertanyaan masih rendah. Untuk kelompok pasar minggu dan kelompok pasar tahunan perlu bimbingan khusus karena dari 4 aspek, tiga aspek termasuk masih masuk kategori rendah.

Dari observasi siklus I ini dapat ditarik kesimpulan bahwa penerapan pembelajaran dengan metode Contektual Teaching and Learning (CTL) masih perlu diberi motivasi dan bimbingan lagi untuk perbaikan disiklus berikutnya.

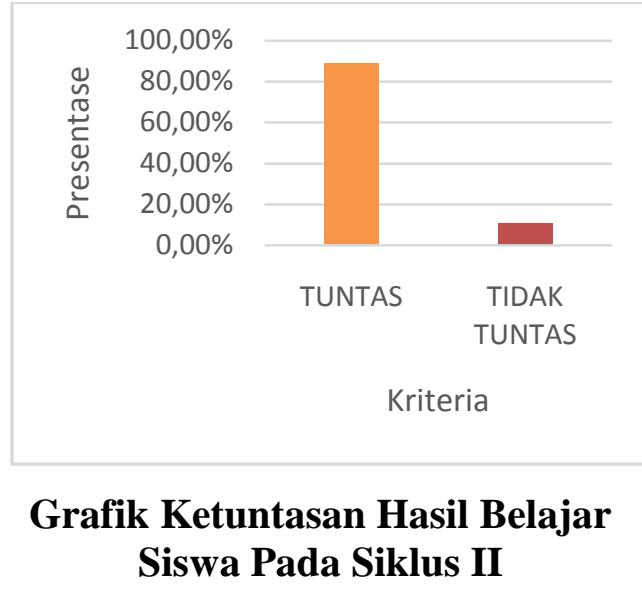

Dari gambar diatasdapat dilihat hasil belajar siswa pada siklus II pada mata pelajaran IPS di SMP Negeri I Stabat Kelas VIII- H dengan menggunakan metode Pembelajaran Contektual Teaching and Learning $(C T L)$, diperoleh hasil belajar siswa 33 orang tuntas belajar atau sekitar $89,18 \%$ dan 4 orang atau sekitar $10,81 \%$ tidak tuntas belajar.

Dari hasil belajar tersebut terjadi peningkatan dari siklus I ke siklus II, hasil belajar diatas dapat disimpulkan telah mencapai ketuntasan belajar secara klasikal yang ditargetkan yaitu $85 \%$ tuntas belajar dalam 1 kelas.

Untuk itu pembelajaran dengan menggunakan metode Pembelajaran Contektual Teaching and Learning (CTL) diberhentikan dalam penelitian tindakan kelas kali ini. 


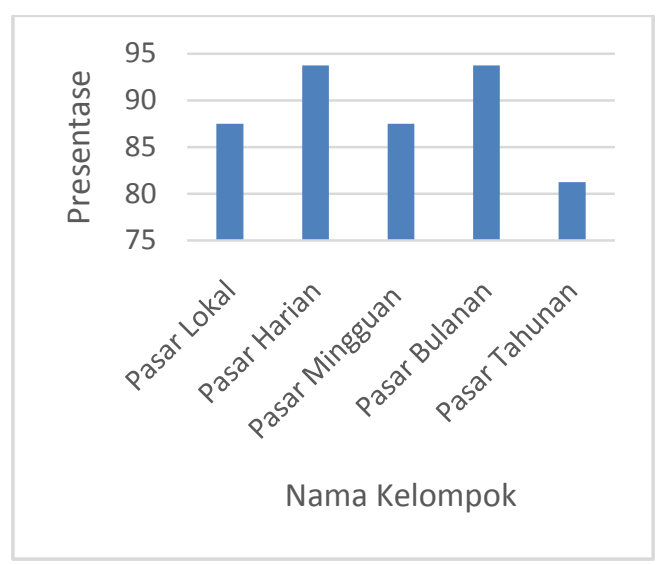

Grafik Observasi Aktivitas Siswa Dalam Presentasi Pada Siklus II.

Dari gambar diatas dapat dilihat bahwa aktivitas yang diamati selama pembelajaran dengan menerapkan metode Pembelajaran Contektual Teaching and Learning (CTL) ada 4 aspek yang diamati yaitu : kemampuan presentasi, kemampuan berargumentasi, kemampuan menjawab dan penguasaan materi. Dari 4 aspek yang diamati dapat dilihat bahwa terjadi peningkatan kemampuan siswa dalam presentase dan penguasaan materi yang sangat baik dalam presentasi, dari segi aspek kemampuan berargumentasi dan kemampuan menjawab pertanyaan juga terjadi peningkatan yang sangat baik. Dari hasil observasi diatas dan hasil belajar siswa diatas dapat ditarik kesimpulan penerapan pembelajaran dengan metode Contektual Teaching and Learning (CTL) dapat meningkatkan aktivitas dan hasil belajar siswa dengan baik.

\section{PEMBAHASAN}

Penerapan pembelajaran dengan metode Contektual Teaching and Learning (CTL) pada pembelajaran IPS pada siswa kelas VIII-H di SMP Negeri 1 Langkat menunjukkan adanya peningkatan ketercapaian indikator hasil belajar siswa dan aktivitas belajar siswa. Berikut ini penjelasan ketercapaian target pada setiap aspek hasil belajar dan aktivitas belajar.

\section{Pembahasan}

Pada siklus I pada mata pelajaran IPS di SMP Negeri I Stabat Kelas VIII- H dengan menggunakan metode Pembelajaran Contektual Teaching and Learning (CTL), diperoleh 23 orang tuntas belajar atau sekitar $62,16 \%$ dan 14 orang atau sekitar $37,48 \%$ tidak tuntas belajar, sedangkan Aktivitas belajar siswa 4 aspek yang diamati yaitu : kemampuan presentasi, kemampuan berargumentasi, kemampuan menjawab dan penguasaan materi. Dari 4 aspek yang diamati dapat dilihat bahwa 3 kelompok dalam aspek kemampuan berargumentasi dan kemampuan menjawab pertanyaan masih rendah. Untuk kelompok pasar minggu dan kelompok pasar tahunan perlu bimbingan khusus karena dari 4 aspek, tiga aspek termasuk masih masuk kategori rendah. Dari hasil siklus I ini hasil belajar dan aktivitas siswa masih belum maksimal dikarenakan: a) Penyampaian materi belum tuntas; b) Tidak menggunakan media secara maksimal; c) Siswa belum jelas terhadap konsepdan materi yang diberikan. d) pembahasan materi dan sumber materi yang tidak maksimal. 
Selanjutnya untuk melakukan perbaikan siklus I peneliti melakukan perbaikan , antara lain: a) Memberi motivasi pada siswa untuk lebih meningkatkan keaktifan dalam proses pembelajaran dan presentase; b) Guru lebih intensif membimbing siswa/kelompok yang mengalami kesulitan. Pada siklus II pada mata pelajaran IPS di SMP Negeri I Stabat Kelas VIII- H dengan menggunakan metode Pembelajaran Contektual Teaching and Learning (CTL), diperoleh hasil belajar siswa 33 orang tuntas belajar atau sekitar $89,18 \%$ dan 4 orang atau sekitar $10,81 \%$ tidak tuntas belajar. Dari hasil belajar tersebut terjadi peningkatan dari siklus I ke siklus II, hasil belajar diatas dapat disimpulkan telah mencapai ketuntasan belajar secara klasikal yang ditargetkan yaitu $85 \%$ tuntas belajar dalam 1 kelas. aktivitas yang diamati selama pembelajaran dengan menerapkan metode Pembelajaran Contektual Teaching and Learning (CTL) ada 4 aspek yang diamati yaitu : kemampuan presentasi, kemampuan berargumentasi, kemampuan menjawab dan penguasaan materi. Dari 4 aspek yang diamati dapat dilihat bahwa terjadi peningkatan kemampuan siswa dalam presentase dan penguasaan materi yang sangat baik dalam presentasi, dari segi aspek kemampuan berargumentasi dan kemampuan menjawab pertanyaan juga terjadi peningkatan yang sangat baik. Dari hasil observasi diatas dan hasil belajar siswa diatas dapat ditarik kesimpulan penerapan pembelajaran dengan metode Contektual Teaching and Learning (CTL) dapat meningkatkan aktivitas dan hasil belajar siswa dengan baik. Sejalan dengan hasil penelitian Khotimah (2011) penerapan CTL dapat meningkatkan hasil belajar siswa, adapun temuan penelitian ini adalah: 1) Implementasi metode pembelajaran Contektual Teaching and Learning (CTL) dapat meningkatkan keberanian siswa untuk mengungkapkan ide, gagasan, dan pendapat sesuai dengan pemahaman siswa; 2) Metode Contektual Teaching and Learning (CTL) membutuhkan sistem kontrol yang baik dari guru terutama pada saat siswa berdiskusi di dalam kelompok maupun saa mengungkapkan pendapatnya sehingga peserta didik benar-benar terlibat aktif dalam mengikuti proses pembelajaran.

\section{SIMPULAN}

$$
\begin{aligned}
& \text { Berdasarkan temuan hasil } \\
& \text { penelitian tentang Upaya } \\
& \text { Meningkatkan Aktivitas dan Hasil } \\
& \text { Belajar Siswa Pada Pelajaran IPS } \\
& \text { Dengan Menggunakan Metode } \\
& \text { Pembelajaran Contextual Teaching } \\
& \text { and Learning (CTL) Di Kelas VIII-H } \\
& \text { SMP Negeri I Stabat Kab. Langkat", } \\
& \text { dapat ditarik kesimpulan sebagai } \\
& \text { berikut : } \\
& \text { a. Pada siklus I hasil belajar siswa } \\
& \text { diperoleh 23 orang tuntas belajar } \\
& \text { atau sekitar } 62,16 \% \text { dan } 14 \text { orang } \\
& \text { atau sekitar 37,48\% tidak tuntas } \\
& \text { belajar, terjadi peningkatan pada }
\end{aligned}
$$


siklus II diperoleh hasil belajar siswa 33 orang tuntas belajar atau sekitar $89,18 \%$ dan 4 orang atau sekitar $10,81 \%$ tidak tuntas belajar.Dari hasil belajar tersebut terjadi peningkatan dari siklus I ke siklus II, hasil belajar diatas dapat disimpulkan telah mencapai ketuntasan belajar secara klasikal yang ditargetkan yaitu $85 \%$ tuntas belajar dalam 1 kelas.

b. Hasil pengamatan aktivitas belajar siswa diperoleh data sebagai berikut, untuk siklus I memperoleh nilai diantaranya: Kelompok Pasar lokal 62,5, Kelompok Pasar harian 68,75, kelompok Pasar mingguan 50, Kelompok pasar bulanan 68,75 dan kelompok pasar tahunan 56,25 terjadi peningkatan yang signifikan pada siklus II yaitu: Kelompok Pasar lokal 87,5, Kelompok Pasar harian 93,75, kelompok Pasar mingguan 87,5, Kelompok pasar bulanan93,75 dan kelompok pasar tahunan 81,25. Dapat ditarik simpulan bahwa pembelajaran dengan menggunakan Metode Pembelajaran Contextual Teaching and Learning (CTL) juga dapat meningkatkan aktivitas belajar siswa.

\section{DAFTAR RUJUKAN}

Ali, Muhammad, 2008. Guru Dalam Proses Belajar Mengajar, Bandung: Sinar Baru Algensindo.

Agus Suprijono, 2010. Cooperative Learning, Jakarta: CTSD.

Hartono. 2008. PAIKEM Pembelajaran Aktif, Inovatif, Kreatif, Efektif, danMenyenangkan, Pekanbaru: Zanafa.

Hisyam Zaini, dkk 2011. Pembelajaran Aktif, Jakarta: CTSD

Nana Sudjana,1989. CBSA Dalam Proses Belajar Mengajar, Bandung : Sinar Baru

Rahmayulis, 2002. Ilmu Pendidikan Islam, Jakarta: Kalamulia

Sanjaya, Wina. 2006. Strategi Pembelajaran: Berorientasi Standar Proses Pendidikan. Jakarta: Kencana Prenada Media

Sutardi dan Sudiro. 2007. Pembahaharuan Dalam PBM $D i S D$. Bandung: UPI Press

Winarno Surakhmad. 1980. Metodologi Pengajaran Nasional. Bandung: Jemmars

W.S. Winkel. 1989. Psikologi Pengajaran. Jakarta: Gramedia. 